4. Скакун О. Ф. Теорія держави і права (Енциклопедичний курс): підручник. Вид. 2-е, перероб. і доп. Харків: Еспада, 2009. 752 с.

5. Кудь О.О., Кучерявенко М.П., Смичок С.М. Цифрові активи та їх економіко-правове регулювання : монографія. Харків : Право, 2019. 384 с.

6. Харитонов С.О., Харитонова О.І. IT- право: теорія та практика: навч. посіб. 2-ге вид., доп. Одеса : Фенікс, 2019. 472 с.

7. Арістова І.В., Карпик Ю.А. Вплив цифрової економіки та європейської інтеграції на правотворчість у сфері інтелектуальної власності в умовах розбудови інформаційного суспільства та інформаційного законодавства в Україні. Modern researches: progress of the legislation of Ukraine and experience of the European Union : Collective monograph. Riga : Izdevniecība «Baltija Publishing», 2020. P. 1. 592 p.

8. Спосіб здійснення транзакції 3 передачі цифрової цінності (цифрового активу) та система передачі цифрових цінностей для його здійснення. Патент на винахід. Офіційний сайт компанії Simcord. URL: https://www.simcord.com/ua/ legal-information-patents_(дата звернення: 15.10.2020)

9. Система Bitbon. Офіційний сайт компанії Simcord. URL: https://www.simcord.com/ua/bitbon-system_(дата звернення: 15.10.2020)

DOI https://doi.org/10.30525/978-9934-588-92-1-52

\title{
МЕДІАЦІЯ ЯК ОДИН ІЗ АЛЬТЕРНАТИВНИХ СПОСОБІВ ВИРІШЕННЯ ПРАВОВИХ КОНФЛІКТІВ
}

\author{
Бліхар М. М. \\ доктор юридичних наук, доцент, \\ професор кафедри адміністративного та інформачійного права \\ Навчально-наукового інституту права, психології \\ та інноваційної освіти \\ Національного університету «Львівська політехніка» \\ м. Львів, Украӥна
}

Сьогодні недостатній рівень застосування медіації як способу вирішення правових конфліктів, у тому числі адміністративних суперечок, можна пояснити невисокою поінформованістю громадян про переваги цього способу вирішення правових конфліктів та його переваги над традиційним судовим способом вирішення правових суперечок, 
недостатнім правовим врегулюванням процедури медіації в законодавстві України, відсутністю достатньої кількості професійних медіаторів, які б могли надавати якісні медіаційні послуги, консервативністю як юристів, так i учасників адміністративного процесу на цей момент розвитку правової системи в Україні.

Особливістю виникнення правових конфліктів у реалізації адміністративних правовідносин $\epsilon$ участь як суб'єкта суперечки адміністративного органу чи посадової особи, що його представляс. Ця сторона має значні повноваження, які надаються їй державою, що значною мірою збільшуе в односторонньому порядку іiі вплив на прийняття адміністративного рішення на свою користь. Часто при цьому порушуються основоположні принципи права об'єктивності та незалежності під час здійснення повноважень суб'єкта права. Це впливає на прийняття рішення у справі, що призвела до адміністративної суперечки, на користь саме суб'єкта права, який представляє певні адміністративні повноваження. Крім того, як правильно зазначає Н. В. Боженко, державні службовці обмежені в прийнятті рішень, оскільки відповідно до вимог Коституції України вони зобов'язані діяти лише на підставі та в межах повноважень i у спосіб, визначений законодавством України, а отже, не завжди можуть вирішувати правові конфлікти у позасудовий спосіб [1, с. 46].

Законодавче визначення медіації як юридичної посередницької діяльності, що здійснюється у позасудовій формі і основна фунція якої полягає у вирішенні конфлікту (суперечки) на досудовому етапі шляхом примирення сторін конфлікту і максимального задоволення інтересів обох сторін, з виробленням рішення, що було б прийнятним та позитивним для усіх зацікавлених сторін. Зрештою, застосування медіатора як довіреної сторони усіх учасників адміністративної суперечки допомагає їм у певній конфліктній ситуації адаптуватись до змін, що відбуваються на кількох рівнях одночасно: на психологічному, емоційному, соціальному, правовому i економічному. Тому можна погодитися із зауваженням О. Белінської, що оскільки для сторін правової суперечки головним бажанням повинно бути досягнення мети вирішення непорозуміння, у функції медіатора не входить обов'язок прийняття конкретного рішення, його основне завдання - допомогти сторонам у вирішенні їхнього конфлікту, адже часто предмет суперечки є лише видимою причиною конфлікту [2, с. 161]. При цьому є можливість зберегти конфіденційність інформації, яку незавжди сторони конфлікту хочуть публічно розголошувати в суді, що також сприяє підвищенню ефективності спілкування усіх сторін. Кожна зі сторін має можливість подати своє бачення суті адміністративної суперечки, після чого медіатор визначає 
теми переговорного процесу, окреслюючи важливі моменти, пріоритетність питань, які потрібно розв'язати, і узгоджує між сторонами конфлікту дорожню карту вирішення адміністративної суперечки. Разом із тим залишається можливість документально зафіксувати досягнуті моменти узгодження позицій сторін суперечки. У принципі, сторони конфлікту самі вирішують, за яких умов вони будуть укладати угоду чи припиняти медіацію [3].

Застосування медіаційної процедури на досудовому етапі вирішення правового конфлікту має відбуватися до того часу, коли адміністративний судовий орган не визначить своєї позиції по відношенню до адміністративної справи i не висловить цього у відповідному правовому акті. Крім того, адміністративно-правова суперечка, підвідомча адміністративному суду, може виникнути у зв’язку з дією або бездіяльністю державного органу у сфері управління, що було б відображено в об'єктивованому правовому акті (постанові, рішенні, відповіді). Отже, право застосування процедури медіації передусім повинне бути закріплене за тим суб'єктом адміністративних правовідносин, суб'єктом скарги, який вважає, що його права чи свободи порушені певною адміністративною дією однієї із сторін адміністративної суперечки.

Загалом робота медіатора є певним трудовим процесом, етапами якого можна визначити: відкриття справи та підготовка до іï розгляду; виступ медіатора; проведення переговорів і вирішення конфліктів; застосуванння медіаторської етики, включаючи будь-які відповідні етичні стандарти, що існують у цій сфері. У юридичній літературі зазначається, що навички медіатора повинні охоплювати такі основні питання, які мають бути реалізовані у практичній сфері розв'язання адміністративної суперечки, а саме: навички слухання та комунікативні стратегії, зокрема навички управління процесами, включаючи використання спільних та приватних зустрічей, але не обмежуючись ними; стратегії переговорів і навички управління змістом суперечки; шляхи реагування на різноманітну поведінку сторін.

Можна стверджувати, що медіатор виступає як активна третя сторона адміністративної суперечки, що контролює процес прийняття компромісного рішення суперечки, прийнятного для усіх сторін конфлітку, сприяє реалістичній оцінці ситуації сторонами конфлікту та прийняттю адекватного рішення, зменшує емоційне напруження та ін. [4, с. 156]. При цьому, як зазначає Г. Єрьоменко, основною відмінністю медіації від інших способів вирішення правових суперечок $є$ зосередження уваги сторін, у тому числі медіатора, передусім на досягненні 
загальноприйнятного співвідношення рівня задоволеності інтересів сторін конфлікту [5].

Отже, застосування медіації як способу вирішення адміністративних суперечок може допомогти вирішити проблеми, що нині спостерігаються в українському судочинстві.

Якщо враховувати, що з кожним роком в адміністративних судах зростає кількість справ про адміністративні суперечки між громадянами i юридичними особами, подань до державних органів та органів місцевого самоврядування через порушення прав і свобод фізичних та юридичних осіб, то необхідність створення інституту адміністративної медіації в Україні постає особливо гостро. Отже, є актуальним прийняття і введення в широку правову практику інституту правової медіації - системи спеціалізованих правових товариств, які будуть захищати права громадян i юридичних осіб. Розвиток правової медіації, у тому числі для вирішення адміністративних суперечок, може стати ефективною складовою судовоправової та адміністративної реформ, про які так багато говориться в сучасному суспільстві. Досвід запровадження медіації в адміністративній юстиції зарубіжних країн показує, що раціонально побудована система правової медіації стає додатковим ефективним механізмом захисту прав громадян та юридичних осіб, сприяє вдосконаленню правової держави та дотриманню принципу поділу влади.

Створення системи правових медіаторів, визначення кола їхньої діяльності у національному правовому дискурсі, зокрема в адміністративній юстиції, $\epsilon$ дуже актуальною i потребує законодавчого вирішення. Застосування процедури медіації в українській судовоправовій реформі спрямоване на подальше формування демократичної правової держави, яка гарантує повагу та гідність особи, іiі права і свободи, справедливість у вирішенні будь-яких правових конфліктів. Медіація повинна стати одним із основних гарантів дотримання принципів правової держави, допомогти судовій владі як універсальному способу правового захисту прав і свобод громадян та юридичних осіб. Зокрема, стовідсоткове виконання сторонами конфлікту рішень, запропонованих медіатором, своєю чергою буде сприяти підвищенню авторитету правових медіаторів та правової медіації як інституту та процедури вирішення правових конфліктів.

\section{Література:}

1. Боженко Н. В. Впровадження медіації в адміністративних судах України. Науковий вісник публічного та приватного права. 2019. Вип. 2. ч.1. С. 45-48. 
2. Белінська О. В. Медіація - альтернативне вирішення спорів. Вісник Вищої ради юстииї̈. 2011. № 1(5). С. 158-173.

3. Єрьоменко Г. Перспективи розвитку медіації в Україні. URL: http://www.ukrmediation.com.ua/files/content/Perspectyvy.pdf (дата звернення: 04.10.2020).

4. Кафарський В. В. Медіація в адміністративному судочинстві. Прикарпатський юридичний вісник. 2014. Вип. 3(6). С. 152-165.

5. Срьоменко Г. Медіація - альтернативний спосіб розв'язання конфліктів, або і вівці цілі, і вовки не голодні. Маркетинг в Украйні. 2011. № 5. C. 67-70.

DOI https://doi.org/10.30525/978-9934-588-92-1-53

\title{
ДОВІРА ДО ВЛАДИ В СИСТЕМІ ЗАХИСТУ ІНТЕРЕСІВ ГРОМАДЯН
}

\author{
Булгакова О. В. \\ кандидат економічних наук, дочент, \\ дочент кафедри державно-правових дисииллін \\ Донецького юридичного інституту \\ Міністерства внутрішніх справ Украӥни \\ м. Кривий Ріг, Дніпропетровська область, Україна
}

Сучасна практика управління за умови демократизації суспільного життя і розвитку ринкової економіки стикається з питаннями мало ефективності сталих традиційних організаційно-управлінських засобів і заходів та порушує питання про необхідність пошуку нових шляхів вирішення питань в управлінні та запровадження нових форм урядування, які здатні вирішувати складні сучасні проблеми. В складній системі суспільства урядування можна розглянути як застосування економічної, політичної та адміністративної влади для досягнення успіху в реалізації задач державного управління на всіх рівнях. Таке урядування охоплює механізми, процедури та інституції, за допомогою яких громадяни та певні групи громадян здатні висловлювати та реалізовувати свої інтереси, реалізовувати в повному обсязі свої юридичні права та врегульовувати суперечності [1, с. 103].

Складно заперечити, що однією 3 найважливіших проблем сучасного розвитку суспільства $є$ питання ефективності взаємовідносин 218 